\title{
RESEARCH POSSIBILITIES OF EXTREME HYDROLOGICAL PHENOMENA IN SERBIA IN THE FUNCTION OF CLIMATE CHANGE ADAPTATION
}

\author{
Goran Anđelković* ${ }^{* 1}$ Ivan Samardžić*, Duško Đukić \\ *University of Belgrade-Faculty of Geography, Belgrade
}

\begin{abstract}
Many natural disasters are nowadays interpreted as consequences of climate changes. They represent a form of extreme occurrences, i.e. deviation of normal conditions. They are recognized as deviation in the intensity, frequency or spatial distribution of a phenomenon from normal conditions. Thus, they represent a threat to ecosystems, economic stability and can lead to social and political problems. So far, there is no generally accepted classification of the disasters. This paper starts from the fact that a special grouping represents disasters that are happening as result of interaction of atmosphere and hydrosphere, due to the mutual interconnections. It is considered that the genetic grouping of climatehydrological extremes represents the majority of natural disasters. In the near past, the Southeast Europe countries were exposed to hydrological extremes whose causes were atmospheric occurrences. Due to the region's compactness and similar geographical conditions, these countries were sensitive to similar phenomena. The paper discusses about the hydrological extremes in Serbia that represents the result of extreme climatic conditions in relation to the consequences they have in the geographical surrounding. A total of 19 extreme hydrological phenomena have been outlined in this paper. Based on the level of destructiveness, they are classified into five categories: exceptional, significant, dangerous, strong and catastrophic. Each of them can be identified using statistical thresholds as physical parameters. The type of distribution basically determines the way in which thresholds are calculated. Four methods for their detection are outlined: the normal distribution method, the peaks method, the deciles method and the recurrence interval method. Defining
\end{abstract}

1 Corresponding author: G. Anđelković, University of Belgrade-Faculty of Geography, Belgrade. e-mail: andelkovic@ptt.rs 
each unfavorable phenomenon, their classification and determination of methods for detection are conditions for recognition and announcement. This allows an adequate reaction from the social community and the risks of disasters are reduced.

Keywords: extreme hydrological phenomena, Serbia, disasters, floods, thresholds.

\section{Introduction}

Hydrological phenomena are a direct or indirect reflection of processes and conditions in the atmosphere. Cognition of the concrete forms of that relation is very important, especially in the sphere of the research of extreme occurrences, which are manifested as natural disasters (IPCC, 2007, 2009, 2013). They have become one of the biggest problems in the world, but in science there is no generally accepted classification of the disasters (Gavrilović, 2007). Their division, ranking according to the degree of risk and terminology definitions, are the subject of the nowadays numerous researches when various aspects of climate change are being examined increasingly (Sanderson, 2010; Lupikasza, 2010; Trbić et al., 2011; Ducić et al., 2015, Dabral et al., 2016; Rajczak et al., 2013; Rulfová et al., 2017). This paper starts from the fact that clear identification of extreme hydrological phenomena (EHP) on a specific territory can identify climate changes and increase the nation's resistance.

Numerous changes in the natural environment made by human have caused changes in the hydrological conditions on Earth. All this is attached by the influence of the discovered climate changes that are becoming (taking on) increasingly important due to the connection of the atmosphere - hydrosphere system (Dhakal \& Sidle, 2004; Wheater, 2002; Konikow \& Kendy, 2005; IPCC, 2009 , 2013). „The behavior of the atmosphere is also highly interlinked with that of the hydrosphere, cryosphere, and terrestrial environment so that extreme (or sometimes non-extreme) atmospheric events may cause (or contribute to) other rare physical events" (Lavell et al., 2012). As numerous climatic models present, the influence of different changes in the precipitation patterns is dominant among many regions of the world. Changes in the global hydrological cycle as response to warming will not be uniformed in the $21^{\text {st }}$ century. Contrasts in precipitation between dry and humid regions, as well as between wet and dry seasons, will be deepened, although there is a possibility of regional exceptions (IPCC, 2013).

The goal of this paper is to isolate, define and classify all hydrological phenomena in Serbia which represent an extreme event in the environment. It is considered that they also represent a reflection of the climate conditions of that space and whose change is the manifestation of climate change in a certain pe- 
riod of time (Gocić \& Trajković, 2013; Mustafić et al., 2013; Malinović-Milićević et al., 2016). Identification should be based on statistical criteria. In this way, the methodology for identifying defined extreme hydrological phenomena (EHP) is addressed as problem (https:// www.globalchange.gov). The resolution of this problem was set as the first and basic task of this paper, while the second task was to consider the certainty of the impact of extreme precipitation as the most characteristic element and factor of the hydrological conditions of the studied territory.

The territory of Serbia is climatically differentiated due to its location and orography. In studying EHP, it should be taken into account that Serbia generally has the greatest experience with unfavorable phenomena related to the atmosphere-hydrosphere system, such as droughts, floods (heavy rain and long - lasting rain), storms (hail, wind, rain and thunderstorms), frost, black ice, (including snowstorms), high snow, low and high temperatures (Oikonomou et al., 2008; Milanović et al., 2010; Ristić et al., 2012; Tošić \& Unkašević, 2013; Milanović et al., 2015; Milovanović et al., 2017).

Due to extreme precipitation, Serbia and the countries in its surroundings suffer large damages from large floods. The largest flood occurred in 2014, when a strong cyclone covered almost the entire Balkan Peninsula, where large amounts of precipitation were excreted on the territories of several neighboring countries (Stadtherr et al., 2016; Tošić et al., 2017). It was estimated that the total value of destroyed goods in Serbia, in 24 floods affected municipalities, reached 1.525 million EUR (http:/ / www.obnova.gov.rs).

However, regarding other parts of the world, Serbia is greatly spared from disasters. Therefore, until very recently, the interest for their complex studying was not so pronounced. Floods, heavy rain and extreme temperatures have been studied more (Gavrilović, 1981; Unkašević \& Radinović, 2000; Unkašević et al., 2005; Anđelković 2006, 2007, 2010, 2015; Anđelković \& Živković, 2007; Gocic \& Trajkovic, 2013; Gocić \& Trajković, 2014). For the concept of this paper, "The proposal of the methodology for the detection and investigation of extreme weather and climatic phenomena" is important, which was used as a material in the operations of the Working Group 5 (Small - scale dangerous weather phenomena) at the IPCC Seminar in Beijing, 2002 (Radinović \& Maksimović, 2002).

\section{Classification of extreme hydrological phenomena}

A large group of natural disasters includes unfavorable occurrences that are the result of the interaction between atmosphere and hydrosphere. It is considered that these extremes constitute the vast majority of all natural disasters. Some phenomena in the hydrosphere can be detected almost simultaneously 
with causative phenomena in the atmosphere, and some occur with delay. The geographical distribution of extremes refers to the characteristics of the presence of the phenomena in the space - areal.

All EHP are classified into five categories: extraordinary phenomena, significant phenomena, dangerous phenomena, strong phenomena and catastrophic phenomena. The division was done accordingly to the damage they cause or can cause, i.e. level of destructiveness. Also, it is based on studies of this kind carried out for Serbia (Radinović, 1990; Radinović, 1997; Maksimović, 1987; Anđelković, 2010). Total of 19 EHP are classified into all categories, including phenomena that are basically of meteorological nature, but are directly projected onto the hydrosphere.

Extraordinary hydrological phenomena include phenomena that lead to disturbances in people's lives and activities, but do not directly endanger lives or material goods. Such phenomena are:
a) water level on rivers significantly below of regular,
b) level of groundwaters significantly below of regular,
c) level of groundwaters significantly above of regular,
d) drying up of springs.

Significant hydrological phenomena are considered phenomena that can lead to endangering people and material goods. Genetically, they are meteorological phenomena that can cause a sudden increase in water levels and flooding, spread of ice or large waves on rivers. These phenomena are:
a) suddenly meleting of snow cover,
b) intensive and long-lasting rains,
c) heavy and long-lasting frosts,
d) storm wind.

Dangerous hydrological phenomena are considered as phenomena that endanger the lives of people or cause direct material damage. Those are:

a) water level on rivers significantly above regular,

b) effusion of the flash flood,

c) large ice on navigable rivers,

d) high waves on navigable rivers.

Strong (potential katastrophic) hydrological phenomena includes phenomena that can cause human casualties and material damages that have catastrophic scale. These are widespread and extremely intense meteorological and hydrological phenomena. Such phenomena are:

a) widespread and intensive rains,

b) widespread and intensive melting of snow cover,

c) flood waves on upstream water surface profile of many rivers which superimpose. 
Within catastrophic hydrological phenomena belong those, which by their spatial scales or intensity, reach extreme values whose consequences are inconceivable. Such phenomena are:

a) water level on navigable rivers which reaches or overcomes absolute maximum,

b) effusion of many flash floods at the same time,

c) level of underground water that reaches or overcomes absolute minimum,

d) level of underground water that reaches or overcomes absolute maximum.

\section{Methods of determining the thresholds for extreme hydrological phenomena}

Statistical methods used in the exploration of hydrological events have been elaborated a long time ago. We will consider the procedures which can be applied to the phenomena outlined in this paper. The type of distribution basically determines the way in which thresholds for hydrological extremes are calculated. Four methods for detecting extreme hydrological phenomena are outlined: the normal distribution method, the peaks method, the deciles method and the recurrence interval method.

An ideal case of the frequency distribution of a statistical set shows normal or Gauss's distribution. For a random variable $X$, it is said to have a normal distribution if its density (for $-\infty<x<+\infty$ ) is given by the function:

$$
f(x)=\frac{1}{\sigma \sqrt{\pi}} \exp \left\{-\frac{(x-\mu)^{2}}{2 \sigma^{2}}\right.
$$

. Here $\mu$ and $\sigma$ are distribution parameters, $\mu$ representing the mean value, $\sigma^{2}$ the standard deviation and dispersion (variance) of the distribution. The density graph $f(x)$ of the equation has the form of a bell and represents an ideal case under the assumption that deviations from the mean value or deviation $(d)$ are independent of each other.

When it is found that the series of data "quite correspond" to Gauss's law, the classification of the climatic elements by Chapman (1919) is applied. On the basis of exactly defined numerical values, it describes the degree of "normality" (Table 1). Thereby, the values that situate within the interval $\mu \pm \sigma$ are taken for normal values. An example is the air temperature which leads to the sudden melting of the snow cover. 
Table 1. Classification of events according to the degree of "normality" and example of air temperature

\begin{tabular}{|c|c|c|}
\hline Classes & Climate characteristics & $\begin{array}{c}\text { Temperature } \\
\text { characteristics }\end{array}$ \\
\hline below $\mu-3 \sigma$ & extreme subnormal & extreme cold \\
\hline from $\mu-2 \sigma$ to $\mu-3 \sigma$ & very subnormal & very cold \\
\hline from $\mu-\sigma$ to $\mu-2 \sigma$ & subnormal & cold \\
\hline interval $\mu \pm \sigma$ & normal & normal \\
\hline from $\mu+\sigma$ to $\mu+2 \sigma$ & below normal & warm \\
\hline from $\mu+2 \sigma$ to $\mu+3 \sigma$ & much above normal & very warm \\
\hline above $\mu+3 \sigma$ & extreme above normal & extreme warm \\
\hline
\end{tabular}

Source: Chapman (1919)

For extreme values of hydrological parameters whose distribution of frequencies is not normal, but rather characteristic by peaks (e.g. rainfall maximum, water level on rivers, groundwater level, etc.), the method used is the peaks method. In the literature, this method is known (Vukmirović, 1990) as the method of partial series or the peaks-over-threshold method. Unlike the previous one, this would be a model of discontinued distribution. The most common models of discontinued distribution are the Bernoulli binary and the Poisson distribution.

The extreme value is between the threshold and the maximum value of the given phenomenon, i.e.: $\Phi_{P} \leq \Phi_{E} \leq \Phi_{M}$. $\Phi_{P}$ is threshold value, $\Phi_{E}$ is extreme value and $\Phi_{M}$ is maximum recorded value.

The use of the peaks method is used to analyze the three basic characteristics of the extremes: the number of peaks in the year or season, the height of the peaks and the maximum annual values or seasonal annual values of the hydrological parameters.

The threshold value is determined as the mean value of the extreme annual sizes of an element for the analyzed period. In other words, there are calculated the mean annual minimum and (or) mean annual maximum values of the parameters considered as extreme phenomena:

$$
\phi_{P}=\frac{1}{n} \sum_{i=1}^{n} \phi_{M}
$$

Here $\Phi_{p}$ is threshold value, $M_{i}$ represents maximum values in each $i$ year and $n$ the number of years of the observed period.

While some random variables follow the normal or some other known distribution, others will not have any known distribution. This is the case with the 
distribution of frequency of the number of stations or network points, which describes the extreme hydrological phenomena. In this case, the frequency distribution method should be used, whereas it does not depend on the shape of the distribution. Such method is explained in detail by Vujević (1956), and recommended by Gibbs (1987).

It is about the deciles distribution ranges, and the method can be called the deciles method. Deciles occur when the members of group are divided into ten equal parts, as per $10 \%$ of the members of the statistical set distributed by frequency. The deciles calculation formula $\left(D_{x}\right)$ is:

$$
D_{x}=L_{D}+\frac{\frac{N}{\mathbb{D}}-f_{k}}{f_{a}} \cdot i
$$

The meaning of the sign marks in the formula is as follows: $x$ - the deciles number, e.g. the tenth decile is $D_{10^{\prime}} L_{D}$ - the lower limit of the deciles class, $N$ - the total number of members of the series, $f_{k}$ - cumulative frequency of the class preceding the deciles class, $f_{a}$ - frequency of the deciles class and the $i$ - class interval.

The term "normal" is used to express the values of the frequencies between the third and seventh deciles. The adequate terminology is in Table 2. Catastrophic phenomena are considered phenomena whose distribution belongs to the last decile, i.e. in the category of very much above normal.

Table 2. Decile's ranges of the frequency distribution

\begin{tabular}{|c|c|c|}
\hline Designations & Procents & Deciles \\
\hline very much above normal & below 10 & 1 \\
\hline much above normal & $10-20$ & 2 \\
\hline below normal & $20-30$ & 3 \\
\hline normal & $30-70$ & $4-7$ \\
\hline above normal & $70-80$ & 8 \\
\hline much above normal & $80-90$ & 9 \\
\hline very much above normal & above 90 & 10 \\
\hline
\end{tabular}

Source: Gibbs (1987)

For some hydrological phenomena and their statistical variables, there are no inherent characteristics based of which the thresholds for values above the normal can be identified (effusion of the flash floods, thick ice on navigable rivers, etc.). The recurrence interval method is used for such cases. It would be expressed in years (due to occurrence of one season per year) and would be based on the probability theory. An interval would be determined with a chance that the event will occur at least once within that interval. 
The probability of an event $(P)$ is expressed as a quotient of the number of actual occurence $(f)$ and the number of possible occurrence $(N)$ :

$$
P=\frac{f}{N}
$$

The recurrence interval $\left(T_{X}\right)$ is defined by the term:

$$
T_{X}=\frac{1}{1-P}
$$

By definition, the probability is within the boundaries: $0 \leq P \leq 1$. Consequently, the recurrence interval can have values: $1 \leq T_{X} \leq \infty$.

For practical reasons, this method allows that thresholds of extreme values of hydrological phenomena to be determined at intervals in which they have a probability to occur at least once in a given period. Due to the multitude occurrences which can be manifested at shorter intervals, the recurrence interval method can usefully serve to upraise the criteria and thereby minimize the frequency of warnings that would not have practical benefits.

\section{Results}

Identification of extreme hydrological phenomena implies the calculation of thresholds as limit values for extremeness. Thresholds are the limits of the normality of the climate. Changing the quantitative characteristics of the abovethreshold phenomena can be examined as a result of climate changes. On this occasion, it is necessary to distinguish short-term fluctuations from long-term changes and their trends. The normal climate periods defined by the World Meteorological Organization or some other relevant multiannual periods should represent the frameworks of such testing. The methodology for determining the threshold EHP is based on the methodology of determining extreme climate phenomena elaborated by Anđelković $(2010,2015)$, as well as on the methodology developed by Radinović $(1990,1997)$. Frequency and intensity are the most important indicators.

\section{Determination of thresholds for extraordinary phenomena}

It is assumed that data of water level on rivers are not the subject to normal distribution. Therefore, thresholds for very low water levels are calculated using the peaks method. For the threshold is taken the mean value obtained from the annual minimums during the investigated period (thresholds are calculated for all significant river profiles in Serbia. 
The function of the groundwater level distribution is unknown. It should be tested for each area separately (Banat, Mačva, etc.), but it is very likely that the level of groundwater does not follow the regular distribution, considering it is in an direct connection with the water level of rivers, thus the peaks method will be used as well, where the mean value of the annual minimums according to the formula will be taken as the lower limit, as well as for the water level on rivers significantly below the regular.

For calculating the threshold which determines the level of groundwater well above the normal, the same methodology can be used, as well as to determine the threshold for the level of groundwater significantly below the normal. In this case, only the mean value of the annual maximum is calculated.

Based on the data from the "cadastre" of springs in Serbia and the records of their discharging and drying up at certain time intervals, by using the deciles method a threshold is calculated by which the number of dried springs is considered to be an exceptional hydrological phenomenon.

\section{Determination of thresholds for significant (potential dangerous) hydrological phenomena}

When strong melting in our regions appears in March and April and the temperature overcomes the threshold above the normal temperature, snow melting occurs suddenly. The basic parameters for this phenomenon are the air temperature significant above the normal and the length of certain warm period. Anđelković (2010) dealt with the exploration of these thresholds. The length of the period with a temperature significant above the normal should be equal to or greater than the longest period of time that occurred in the last climate period.

Two types of rainy situations often lead to the effusion of rivers and major floods. First, it is a situation when the rain falls, which by its intensity overcomes the average value of the maximum daily precipitation per year of certain multiannual period. This is a typical indicator of the extreme hydrological situation. Second, if the number of consecutive rainfall days overcomes the mean length of the maximum annual periods for the last climate period. Both situations represent potentially dangerous hydrological phenomena. Their thresholds are determined by the peaks method.

Under heavy frosts are so-called frosty days when the air temperature does not overcome $0{ }^{\circ} \mathrm{C}$ at any moment. Long-lasting frost represents the number of consecutive frosty days which overcome the average number of days of the longest periods during the last climate period (the peaks method). Heavy and long-lasting frosts are significant for leading towards partial or complete freezing of the river. 
The storm wind, i.e. 8 or more Beaufort number, either over $17.2 \mathrm{~m} / \mathrm{s}$, represents a double potential danger to river flows. First, such wind produces high waves which make navigation difficult and represents danger to vessels. Secondly, such strong wind blows can overturn and sink smaller vessels or barges on rivers.

\section{Determination of thresholds for dangerous hydrological phenomena}

At high water level, the changes of level do not reflect the real "image" of river flow due to the effusion of water outside the riverbed on certain sections. Therefore, it cannot be expected that the distribution of high values of water levels would be regular. That is why is suitable to use the peaks method for calculating threshold of floods. In order to calculate the threshold of floods on various profiles, it is necessary to take the maximum annual water levels for all years of the normal climate (explored) period, but also their mean value should represent that threshold.

Many river flows in Serbia, especially short ones and in mountain areas, are not yet regulated or protected from effusion. That is why the flash floods occur during heavy rains or long-lasting rains. They usually flood the settlements and therefore represent dangerous hydrological phenomena.

The term "large ice" connotes to the appearance of ice on navigable rivers that cover over $50 \%$ of the water surface. Then, it leads to accumulation on certain flow sections, blocking the vessels, effusion of water from riverbeds and other dangers.

High waves represents great danger especially for the convoy of barges and smaller vessels. They occur under the influence of strong wind, but their size depends on other factors related to the features of riverbed and coastal area. To determine the height thresholds above which the waves begin to make a real danger, it is necessary to use the technical standards for river navigation related to this sphere.

Determination of thresholds for strong (potential katastrophic) hydrological phenomena

Widespread rains represent a potentially catastrophic hydrological phenomena, corresponding to situations where the number of synoptic stations in which the recorded amount of precipitation is above threshold for the peaks within the last decile.

Such wide zones of intensive precipitation lead to simultaneous confluence of large quantities of water into the majority of riverbeds and therefore lead to numerous widespread floods. 
Extremely intensive rains also represent a potentially catastrophic hydrological phenomenon. When the daily amount of rain reaches or overcomes the absolute maximum observed in the last climate period on some weather stations, it represents an extreme hydrological phenomenon.

The widespread melting of snow cover that represents a potentially catastrophic hydrological phenomenon occurs when the number of synoptic stations in our country, which in March or April observe the temperature significantly above normal belong to the last decile per its frequency.

Extremely intensive melting of snow cover gets the character of a potentially catastrophic hydrological phenomenon when some of the synoptic station in March or April record a temperature equal to or greater than the absolute temperature observed in the last normal climate period.

Sometimes situations occur that, due to abudant amounts of precipitation or sudden melting of the snow cover, come to simultaneous formation of flood waves on a number of upstream profiles and on several tributaries of certain larger river. If these waves on most of the upstream profiles exceed the thresholds determined by the peaks that represents a potentially catastrophic hydrological phenomenon.

\section{Determination of thresholds for catastrophic hydrological phenomena.}

One of the most characteristic hydrological phenomena is water level on navigable rivers that reaches or overcomes the absolute value recorded during the last climate period. This would lead to flooding of enormous arable fields and whole series of coastal settlements.

In situations when come to effusion of many flash floods at same time, i.e. when the water levels of these rivers overcomes the thresholds (peaks), the flooding of more coastal settlements, arable fields, roads, railroads and other important facilities and human casualties, usually occurs. Therefore, such situations represent the real catastrophic hydrological phenomenon, which should be specifically recorded and, if are possible, "announced".

When the level of underground water extremely elevates, then pushes out to the surface, fills in basements, floods settlements in the lowlands, pollutes the water wells, conditions many infections, soaks roads and inflicts many other damages which represents the real hydrological catastrophe. Therefore, this phenomenon, as well as other catastrophic phenomena, must be specifically recorded and timely announced.

In case when level of the underground water reaches or overcomes absolute minimum from the last climate period, then there is a huge perturbation in the hydrological cycle. Springs dry up, supplying with water to a series of 
settlements is very difficult, plants and crops are drought, because they get out of water and become incalculable damages that represent a real hydrological catastrophe.

\section{Discussion and conclusion}

The quoted ways of identifying EHP enable to test their trends and as such to detect the effects of climate change. Of course, extreme hydrological occurrences have always appeared, but the increase in intensity and frequency of extrems can be related to anthropogenic effect in space. Climate is the most important factor in EHP, but there are some phenomena (e.g. flooding) that may have human components to causation other than that related to the climate (e.g. land use or land cover change or changes in water management) (Lavell et al., 2012).

We will now consider only intensive precipitation as the most characteristic phenomena in the hydrological cycle and the most important indicator of the impact on hydrological extremes. Many studies have indicated an increase of the precipitation extremes in whole Europe (van den Besselaaret al., 2013; Klein Tank \& Können, 2003; Zolina et al., 2009).

The threshold for intensive precipitation was calculated using the peaks method only for Belgrade from the normal climate period (1961 - 1990). Its value is $43.1 \mathrm{~mm}$. During this period, the threshold was broken through 15 times. It was found that the threshold was overcome 13 times in the next 25 years (19912015). At that time, the thresholds were overcome in March, April, October and November, which was not the case before 1991. The most critical months are July and June with 9, apropos 8 cases of extreme precipitation. Also, it notices some correspondence with the research of Petrović et al. (2014) where the largest number of floods in Serbia appears in June (27.5\%), in May (21\%) and in July $(10.4 \%)$. In the five-year period following the dynamics of extreme precipitation in Belgrade after 1990 is 3, 1, 6, 0 and 3. This rate cannot show the trend of appearance of extremes and indicates the research complexity of the consequences of climate change.

The problem of defining the reference period for calculating the thresholds remains. Thus, depending on the taken time, the size of the thresholds changes. On the basis of these, all other features of the extremes are tested. Anđelković (2010) analyzed the changes in the thresholds of intensive precipitation in Belgrade from 1946 to 2005. The four fifteen-year periods were taken at the indicated time interval. The normal climate period 1961-1990 was also considered as a referential interval.

The average annual sum of precipitation in Belgrade initially slightly increases, and then decreases, as can be seen from the Table 3. In contrast, the 
threshold for intensive precipitation at first decreased slightly from $45.4 \mathrm{~mm}$, then began slowly to increase, and then suddenly pounced in the last period to $54 \mathrm{~mm}$. According to the predicted methodology, the threshold is counted on the daily level, and then its course is compared with the course of absolute daily maximums. All this fits into the knowledge of contemporary climate changes at which the trend of precipitation on the Earth is difficult to notice, whereas comes to increase in dryness and increase in precipitation in some regions of the world (IPCC, 2013).

The testing of the defined EHPs must be based on very complex and extensive research. A large number of multiannual parameters and occurrences makes a large database. Their comprehensive analysis goes beyond the scope of this paper. This paper gives only general classification and methodology for the detection of EHP, all additional checks and implementation of the described methodology require teamwork.

Table 3. Some indicators of precipitation in Belgrade ( $\mathrm{mm}$ )

\begin{tabular}{|c|c|c|c|}
\hline Period & $\begin{array}{c}\text { Average annual } \\
\text { amount }\end{array}$ & Threshold & $\begin{array}{c}\text { Maximum daily } \\
\text { amount }\end{array}$ \\
\hline $\mathbf{1 9 4 6 - 1 9 6 0}$ & 684.1 & 45.4 & 88.4 \\
\hline $\mathbf{1 9 6 1 - 1 9 7 5}$ & 685.1 & 42.4 & 84.8 \\
\hline $\mathbf{1 9 7 6 - 1 9 9 0}$ & 683.7 & 43.7 & 75.6 \\
\hline $\mathbf{1 9 9 1 - 2 0 0 5}$ & 629.3 & 54.0 & 94.0 \\
\hline $\mathbf{1 9 6 1 - 1 9 9 0}$ & 684.3 & 43.1 & 84.8 \\
\hline
\end{tabular}

Source: Authors (based on data RHMS of Serbia)

The results of this paper can help to form a system approach of statistically rare occurrences. Trends of unfavorable hydrological occurrences can be identified in such manner. Also, the system of warning and management of the infrastructure for protection from both hydrological extremes would be enhanced, either a lack or a surplus of water. Intensive activities are justified for the early detection of EHP and large investments in water resources management.

Based on the calculated thresholds it is possible to test the extremes in the past, bring them in conjunction with the damage caused. These can help in estimating the resistance of existing infrastructure and planning future engineering projects. The management of water resources would connotes the planning of infrastructure projects such as waterworks, channels, embankments, dams, etc. Coordination of the meteorological and hydrological observation system is necessary. The pronounced heterogeneity of the territory of Serbia and Southeast Europe, especially regarding relief, is an aggravating circumstance. Also, there are organizational and financial problems, as well as education of the population in the sphere of respecting recommendations and warnings. 


\section{References}

Anđelković, G. (2006). Methodology of determination of extreme air temperatures thresholds in eastern Serbia (Negotin town): in january and july. Bulletin of the Serbian Geographical Society, Belgrade, 86 (1), 61-72.

Anđelković, G. (2007). Temperature conditions on July 2007 as extreme climatic phenomenon in Serbia. Bulletin of the Serbian Geographical Society, Belgrade, 87 (2), 51-62.

Anđelković, G. (2010). Climatic extremes in Serbia - definitions, types and classification. Bulletin of the Serbian Geographical Society, Belgrade, 90 (4), 125-146.

Anđelković, G. (2015). Dužina kišnog perioda kao ekstremna klimatska pojava u Srbiji - rizici i posledice. Zbornik radova sa osmog naučno-stručnog skupa "Planska $i$ normationa zaštita prostora $i$ životne sredine", APP Srbije, Univerzitet u Beogradu Geografski fakultet, Beograd, 371-377.

Anđelković, G., \& Živković, N. (2007). Precipitation as adverse climatic phenomenon in Negotin. Bulletin of the Serbian Geographical Society, Belgrade, 87(1): 51-62

Chapman, E. H. (1919). On the use of the normal curve of errors in classifing observations in Meteorology. Proffesional Notes of Meteorological Office London, 5, London.

Dabral, P. P., Saring T., \& Jhajharia, D. (2016). Time series models of monthly rainfall and temperature to detect climate change for Jorhat (Assam), India. Global NEST Journal, Greece, 18 (3). 494-507.

Dhakal, A. S, \& Sidle, R. C. (2004). Distributed simulations of landslides for different rainfall conditions. Hydrological Processes, 18(4), 757-776.

Ducić, V., Milenković, M., Milijašević, D., Vujačić, D., Bjeljac, Ž., Lović, S., Gajić, M., Anđelković, G., \& Đorđević, A. (2015). Hiatus in global warming - the example of water temperature of the Danube river at Bogojevo gauge (Serbia). Thermal Science Journal, Belgrade, 19 (2), S467-S476

Gavrilović, Lj. (1981). Poplave u SR Srbiji u XX veku - uzroci i posledice. Posebna izdanja Srpskog geografskog društva, 52, Beograd.

Gavrilović, Lj. (2007). Prirodne nepogode kao faktor ugrožavanja životne sredine. Zbornik radova sa Proog kongresa srpskih geografa, Beograd.

Gibbs, J. (1987). Defining Climate.Buletin WMO, 36, Geneva.

Gocic, M., \&Trajkovic, S. (2013). Analysis of precipitation and drought data in Serbia over the period 1980-2010. Journal of Hydrology, 494, 32-42.

Gocić, M., \& Trajković, S. (2014). Spatio-temporal patterns of precipitation in Serbia. Theoretical and Applied Climatology, 117, 419-431.

Intergovernmental Panel on Climate Change (IPCC). (2009). Scoping Meeting for an IPCC Special Report on Extreme Events and Disasters. Managing the Risks, Proceedings [Barros, V., et al. (eds.)], Oslo. 
Intergovernmental Panel on Climate Change (IPCC). (2007). Impacts, Adaptation and Vulnerability. Contribution of Working Group II to the Fourth Assessment Report of the Intergovernmental Panel on Climate Change [Parry ML, Canziani OF, Palutikof JP, van der Linden PJ, Hanson CE (eds.)], Cambridge University Press, Cambridge and New York.

Intergovernmental Panel on Climate Change (IPCC). (2013). Fifth assessment report: climate change 2013 (AR5). IPCC, Chambridge and New York.

Klein Tank, A., \& Können, G., (2003). Trends in indices of daily temperature and precipitation extremes in Europe, 1946-99. Journal of Climate, 16, 3665-3680.

Konikow, L. F., \& Kendy, E. (2005). Groundwater depletion: a global problem. Hydrogeology Journal, 13, 317-320.

Lupikasza, E. (2010). Spatial and temporal variability of extreme precipitation in Poland 1951-2006. International journal of Climatology, 30, 991-1007.

Maksimović, S. (1987). Mesto i uloga meteorologije u zaštiti od lelementarnih nepogoda. Zbornik radova sa proog jugoslovenskog savetovanja "Elementarne nepogode $i$ katastrofe", Beograd.

Milanović, A., Urošev, M., \& Milijašević, D. (2010). Floods in Serbia in the 19992009 period: Hydrological analysis and flood protection measures. Bulletin of the Serbian Geographical Society, Belgrade, 90, 109-121.

Milanović, M., Gocić M., \&Trajković, S. (2015). Analysis of Extreme Climatic Indices in the Area of Nis and Belgrade for the Period between 1974 and 2003. Agriculture and Agricultural Science Procedia, 4, 408-415.

Malinović-Milićević, S., Radovanović, M., Stanojević, G., \& Milovanović, B. (2016). Recent changes in Serbian climate extreme indices from 1961 to 2010. Theoretical and Applied Climatology, Wien, 124 (3-4), 1089-1098.

Milovanović B., Schuster P., Radovanović M., Ristić-Varanjac V., \& Schneider C. (2017). Spatial and temporal variability of precipitation in Serbia for the period 1961-2010. Theoretical and Applied Climatology, Wien, 130, 687-700.

Mustafić, S., Manojlović, P., \& Milošević, M. (2013). Extreme Erosion Rates in the Nišava River Basin (Eastern Serbia) in 2010. In: "Geomorphological Impacts of Extreme Weather. Case Studies from Central and Eastern Europe", Editor Loczy D, Springer, 171-187.

Oikonomou, C., Flocas, H. A., Hatzaki, M., Asimakopoulos, D. N., \& Giannakopoulos, C. (2008). Future changes in the occurrence of extreme precipitation events in eastern Mediterranean. Global NEST Journal, Greece, 10, 255-262.

Petrović, A., Kostadinov, S., \&Dragićević, S. (2014). Theinventory and characterisation of torrential flood phenomenon in Serbia. Polish journal of environmental studies, Olsztyn, 23(3), 823-830.

Public Investment Management Office of Government of the Republic of Serbia. Retrieved from http://www.obnova.gov.rs. 
Radinović, Đ. (1990). Extraordinary, severe and hazardous weather phenomena definitions, forecasts and warnings. Fifth International Youth School on Meteorology and Hidrology, 2, Bulgarian Academy of Sciences, Sofia.

Radinović, Đ. (1997). The basic concept of the metodologies of Mediterranean cyclones an adverse weather phenomena studies. INM-WMO International Symposium on Mediterranean cyclones and hazardous wether phenomena, Palma the Mallorca

Radinović, Đ., \& Maksimović, S. (2002). Proposal for methodology detecting and researching of extreme weather and climate events. Urbanistički zavod Republike Srpske, Banja Luka.

Rajczak R., Pall, P., \& Schär, C. (2013). Projections of extreme precipitation events in regional climate simulations for Europe and the Alpine Region. Journal of Geophysical Research, 118, 3610-3626.

Republic Hydrometeorological Service of Serbia, Retrieved from http://www. hidmet. gov.rs

Ristić, R., Kostadinov, S., Albomasov, B., Dragićević, S., Trivan, G., Radić, B., Trifunović, M., \& Radosavljević Z. (2012). Torrential floods and town and country planning in serbia. Natural Hazards and Earth System Sciences, 12, 23-35.

Rulfová, Z., Beranová, R., \& Kyselý, J. (2017). Climate change scenarios of convective and large-scale precipitation in the Czech Republic based on EURO-CORDEX data. International Journal of Climatology, 37 (5), 2451-2465.

Sanderson, M. (2010). Changes in the frequency of extreme rainfall events for selected towns and cities. Met. Office of United Kingdom, Exeter, 1-39.

Stadtherr, L., Coumou, D., Petoukhov, V., Petri, S., \& Rahmostorf, S. (2016). Record Balkan floods of 2014 linked to planetary wave resonance. Science Advances, Washington, 1-6.

Tošić, I., \& Unkašević, M. (2013). Extreme daily precipitation in Belgrade and their links with the prevailing directions of the air trajectories. Theoretical and Applied Climatology, Wien, 111, 97-107.

Tošić, I., Unkašević, M., \& Putniković, S. (2017). Extreme daily precipitation: the case of Serbia in 2014. Theoretical and Applied Climatology, Wien, 128 (3-4), 785-794.

Trbić, G., Ducić, V., Rudan, N., Anđelković, G., \& Marković, S. (2011). Extreme precipitation in Republika Srpska (2010 and 2011 analyses). Bulletin of Geographical society of Republic of Srpska, 15, Banja Luka, 81-84.

Unkašević, M., \& Radinović, Đ. (2000). Statistical analysis of daily maximum and monthly precipitation at Belgrade. Theoretical and Applied Climatology, Wien, 66, 241-249.

Unkašević, M., Vujović, D., \& Tošić, I. (2005). Trends in extreme summer temperatures at Belgrade. Theoretical and Applied Climatology, 82. 
U. S. Global Change Research Program. Retrieved from https://www.globalchange. gov

Van den Besselaar, E. J. M., Klein Tank, A. M. G., \& Buishand, T.A. (2013). Trends in European precipitation extremes over 1951-2010. International Journal of climatology, 33(12), 2682-2689.

Vujević, P. (1956). Klimatološka statistika. Naučna knjiga, Beograd.

Vukmirović, V. (1990). Analiza verovatnoće pojave hidroloških veličina. Naučna knjiga, Beograd.

Wheater, H. S. (2002). Progress in and prospects for fluvial flood modeling. Philosophical Transactions of the Royal Society A, London, 360, 1409-1431.

Zolina, O., Simmer, C., Belyaev, K., Kapala, A., \& Gulev, S. (2009). Improving estimates of heavy and extreme precipitation using dailyrecords from European rain gauges. Journal of Hydrometeorology, 10, 701-716. 
